\title{
Xexoxial Endarchy: Visual Poetry and Intentional Community at Dreamtime Village in the Midwestern United States
}

Xexoxial Endarchy: La poésie visuelle dans une " communauté intentionnelle" du Midwest étasunien

Xexoxial Endarchy: La poesía visual y la comunidad intencional en el Dreamtime Village en el Midwest de Estados Unidos

\section{Lily Robert-Foley}

\section{(2) OpenEdition} Journals

Édition électronique

URL : https://journals.openedition.org/ideas/2031

DOI : 10.4000/ideas.2031

ISSN : 1950-5701

\section{Éditeur}

Institut des Amériques

\section{Référence électronique}

Lily Robert-Foley, « Xexoxial Endarchy: Visual Poetry and Intentional Community at Dreamtime Village in the Midwestern United States », IdeAs [En ligne], 9 | 2017, mis en ligne le 13 juillet 2017, consulté le 20 octobre 2022. URL : http://journals.openedition.org/ideas/2031 ; DOI : https://doi.org/10.4000/ ideas.2031

Ce document a été généré automatiquement le 20 octobre 2022.

\section{cc) (†)}

Creative Commons - Attribution - Pas d'Utilisation Commerciale - Pas de Modification 4.0 International - CC BY-NC-ND 4.0

https://creativecommons.org/licenses/by-nc-nd/4.0/ 


\title{
Xexoxial Endarchy: Visual Poetry and Intentional Community at Dreamtime Village in the Midwestern United States
}

\author{
Xexoxial Endarchy: La poésie visuelle dans une " communauté intentionnelle " \\ du Midwest étasunien \\ Xexoxial Endarchy: La poesía visual y la comunidad intencional en el \\ Dreamtime Village en el Midwest de Estados Unidos
}

Lily Robert-Foley

\section{Introduction}

In this sense all the arts have a literary basis, built into their history and their myths. Architecture is no exception. In advanced, or at least sedentary, civilizations, building requires the collaboration of various kinds of tradesmen: bricklayers, carpenters, painters, then electricians, plumbers, glaziers, and so on. In nomadic cultures, dwellings are made by a single person, almost always a woman. Architecture is still symbolic, of course, but its social significations are manifest in the arrangement of dwellings within the camp. The same thing happens in literature: in the composition of some works, the author becomes a whole society, by means of a kind of symbolic condensation, writing with the real or virtual collaboration of all the culture's specialists, while other works are made by an individual, working alone like the nomadic woman, in which case society is signified by the arrangement of the writer's books in relation to the books of others, their periodic appearance, and so on. (César Aira, 1990, trans. Chris Andrews 2009: 57-58.)

Dreamtime Village is an intentional community located in the "Driftless Bioregion" of Wisconsin, in the Midwestern United States. The moniker "intentional community" as it is used by the inhabitants of Dreamtime, indicates a community of people who have 
chosen to live together in cooperation, and share a common vision of what that living together entails ${ }^{1}$. "Intentional community" also has the meaning of a social organism that is somehow set apart from mainstream culture: different, alternative, sometimes radical. In the case of Dreamtime, a group of people, both local and dispersed, have banded together to create a space where artistic experimentation is coupled with communal living and environmental and ecological experimentation, such as permaculture farming ${ }^{2}$. Dreamtime is home to a small press called Xexoxial Editions which publishes a range of experimental writing. One branch of this press is a chapbook series called Xerolage, printed on demand on a Xerox machine (hence the name "Xerolage"). Each chapbook is 25 pages long, and devoted to the work of one visual poet. Xerolage began in 1983, and had published 49 chapbooks at the time this article was written ${ }^{3}$.

2 In this paper I will explore the relationship between social/ecological experiments and visual poetry, using a cross section of Xerolages published since the collection's inception in 1983. As Johanna Drucker (1999: 101) has observed, visual poetry is necessarily wedded to its technological interface and also thus rooted to the place where it occurs. Therefore, the category of visual poetry cannot so much be defined as spliced and grown through resonances between site-specific interests or concerns arising out of the particularities of individual artists' work. It cannot be anchored to a telos to which all visual poetry must obey in order to be dubbed as such. Visual poetry is as diverse in its vision as it is in its landscapes and geographies. It is not one way or another.

3 I will nevertheless attempt to illuminate how the non-theory of visual poetry may in some sense co-mingle with the enactment of an intentional community, and to enunciate the complex connection between social / environmental organization at Dreamtime village and the poetry it publishes. Let us return briefly to the passage cited at the beginning of this article, taken from César Aira's Ghosts (1990 (2009): 57-58). The temptation, when comparing literature and the organization of structures in social space (this includes both architecture and social organization) is to make analogies: to say in a sense that space reflects the literature or that literature the space-that they are somehow representative of each other. This is dangerous territory since we quickly find ourselves in gross over-simplification, in the realm of naive near-mystic alliances. What Aira does here, and what I wish to do in this paper is to homologize: not to render one phenomenon equal or equivalent to another through their figural correspondences, but rather to make comparisons between the internal structures which ground phenomena. In Aira's model, the connection is foundational but not fundamental. I will also discuss how the vector of these homologies is Xerolage's own textual ecology.

4 This task is not made more simple by the observation that one of the motifs the social/ structural organization of Dreamtime and the literature it publishes share is the hope of revision: to do things in new ways, to experiment, whether in poetry, in community, or in one's natural environment. This gesture includes a desire to rewrite the structures of the dominant paradigms that produce and reproduce systems of social hierarchy, environmental destruction, and the reification of literature. In poetry this means searching for new idioms while in social organization this means creating paradoxa, building communities outside the dominant paradigm. 
5 I begin my analysis with Michel Foucault's reading of the calligramme from his work on René Magritte's Ceci n'est pas une pipe:

Dans sa tradition millénaire, le calligramme a un triple rôle : compenser l'alphabet; répéter sans le secours de la rhétorique; prendre les choses au piège d'une double graphie. Il approche d'abord, au plus près l'un de l'autre, le texte et la figure : il compose en lignes qui délimitent la forme de l'objet avec celles qui disposent la succession des lettres; il loge les énonces dans l'espace de la figure, et fait dire au texte ce que représente le dessin... et en retour la forme visible est creusée par l'écriture, labourée par les mots qui la travaillent de l'intérieur, et conjurant la présence immobile, ambiguë, sans nom, font jaillir le réseau des significations qui la baptisent, la déterminent, la fixent dans l'univers des discours. (Michel Foucault, 1973: 26)

In its millenary tradition, the calligramme has a triple role: to compensate for the alphabet; to repeat without the aid of rhetoric; to catch objects in the snare of a double graphic form. First of all it brings text and the figure as close as possible to each other: it composes into lines which delimit the object's shape the lines which constitute the succession of letters; it lodges statements within the space of the figure, and makes the text say what the drawing represents... and in return the visible form is emptied by the writing, belabored by the words which sap it from within and, exorcising the motionless, ambiguous, nameless presence, weave the network of significations which baptize, determine and establish it in the universe of discourse. (Michel Foucault, trans. Richard Howard, 1976: 9-10)

6 In this work, Foucault uses the word "calligramme" to refer to Magritte's painting, although in French the term is often used to refer to Apollinaire's visual poems, for example. In general, in French, the word calligramme is meant to indicate a written text whose form makes a picture: "Texte écrit dont les lignes sont disposées en forme de dessins $\mathrm{s}^{4}$. The exemplary translation by Richard Howard maintains the word calligramme, and it is by no means apparent that this word extends to the whole of visual poetry. However, Willard Bohn in his 1986 Aesthetics of Visual Poetry (1914-1928) translates Foucault's "calligramme" as "visual poetry" (he does not cite Richard Howard's translation, which appeared ten years prior to Bohn's book). He begins his book with this citation and proceeds to found a definition of visual poetry upon it. It is by way of this (mis)translation that I likewise take a (mis)step towards drawing out some homological thematics of visual poetry.

Ainsi le calligramme prétend-il effacer ludiquement les plus vielles oppositions de notre civilisation alphabétique : montrer et nommer ; figurer et dire; reproduire et articuler ; imiter et signifier ; regarder et lire. (Michel Foucault, 1973: 26)

Thus the visual poem claims to abolish playfully the oldest oppositions of our alphabetic civilization: showing and naming; representing and telling; reproducing and articulating; imitating and signifying; looking and reading. (Michel Foucault, trans. Richard Howard, 1976: 9-10)

This quasi mistranslation is useful to us because it grounds a certain history of the visual poem that is critical to its location within poetry today. Visual poetry is far from new. To cite Geof Huth's article on visual poetry, "The original forms of visual poetrythe technopaegnia of classical times and the pattern poetry of the 1500s and beyondwere easier to define. Their hybridization consisted merely of giving conventional poems an essential visual structure." (Huth, 2008) Neither is it by any means limited to the West, as in the Chinese poems à lecture retournée $e^{5}$. Many of these works would be difficult to lump under the moniker "calligramme." Bohn's translation remains interesting however, because of the time period he was working with: 1914-1928, when the calligramme and the visual poem were at an all time high congruence. Exposing 
Bohn's strange over-translation thus traces a line of historical debt from the visual poetry I will be discussing today to the avant garde, not only as poetic opposition, but as social opposition-poetic opposition as social opposition.

It would be erroneous to say that visual poetry ensues from social opposition or that social opposition ensues from visual poetry. What can we say then? Let us return though to the passage cited above from Foucault's Ceci n'est pas une pipe. Foucault invokes what I'll pare down to an explosion of the dual nature of the sign (dual because visible and invisible). Both parts of this duality confront each other in a gesture of mutual undoing. This destructive alliance between the undoing of visual representation by the linguistic unit and the undoing of the linguistic unit by visual representation concomitantly provokes a subversion of alphabetic conventions. These conventions are none other than the conventions of "civilization" as Foucault says.

This paper focuses on the specific place and technologies of the Xerolage collection, and the way that the conventions of "civilization" - as both a reading and a living phenomenon - are taken to task. The method used to treat these works is inspired by the site-specific diversity of visual poetry itself. It is organized the way a finger might run along the spines of books on a library shelf, or hunt through the leaves of a tomato plant for its fruit. It follows a thread of discovery treating six authors, appearing at different moments in Xerolage's printing evolution, and moves organically from one to a next, rather than attempting to present a static view. Reflections upon the ecology of Dreamtime, the running of the press and community, are woven into this exploration, and dialogue with readings of the poems. My aim is to invite readers to explore along with me, this small patch of a great ever growing garden of visual poetry-a garden that has always been growing but has rarely if ever received the same attention as nonvisual poetry or non-textual visual art.

\section{Xerolage \#40 : John M. Bennet}


Image 1

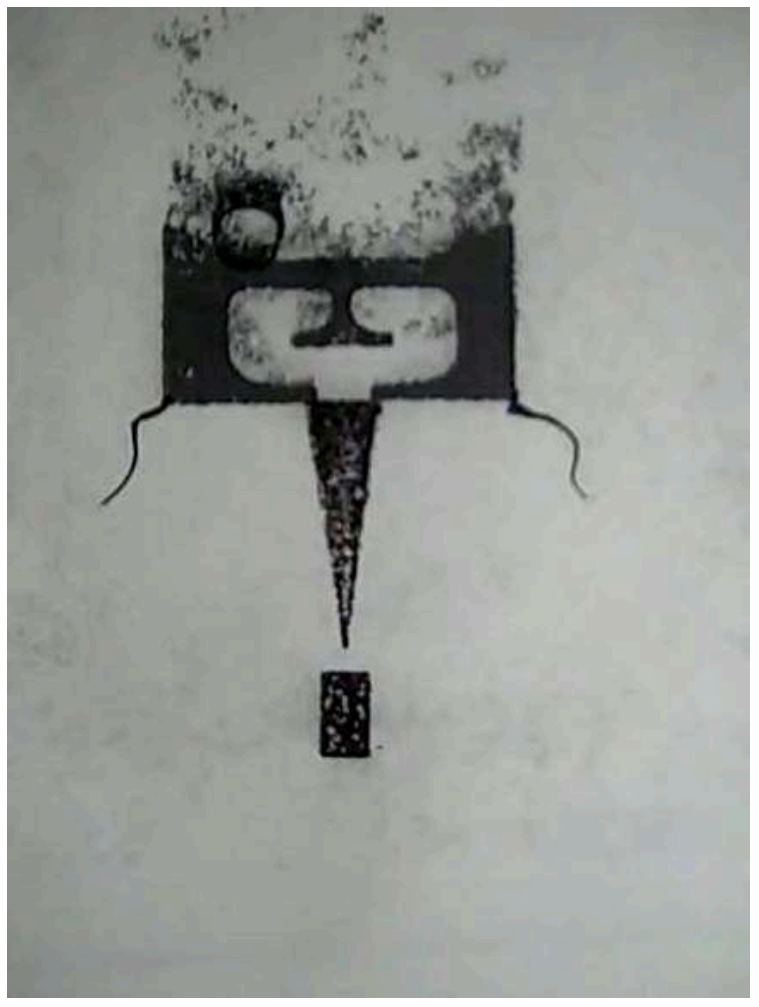

The poems in John M. Bennet's Xerolage \#40 can be characterized as a visual representation of letters (as opposed to a calligramme which is a poem arranged in a visual form).

11 Normally, the tension between the visual representation of the image and the linguistic representation of the grapheme rests in their respective relationships to the play of presence and absence within the signifier: the visual sign dreams of its object, the linguistic sign of its phoneme, or so they say. Therein lies the narrative of the metaphysical tradition as it unfolds in each of these systems of representation, independently. Here, however, we can see how each of these relationships is offset by the other, made to surge up in the other and thus enact the actual complexity of the visual sign's relationship to utterance on the one hand and the phonetic sign's relationship to its visuality on the other.

In this poem, the letter signifies the visual image, and the visual image signifies the letter. It is a strange loop where each dimension deconstructs the other. Here we may see the dual movement of loger (lodge) and creuser (empty, dig out, hollow) that Foucault describes as the simultaneous inhabiting of the énoncés (statements, utterances) in the espace de la figure (space of the figure), and of écriture (writing) in the forme visible (visible form) - although, in Foucault's usage, he is referring to the poem and the shape of the poem, and not to a letter and a phoneme which have become a poem.

In this image, the graphic, visual dimension of the verbal sign is offset by the verbal dimension of the visual sign. Both writing and drawing are present in the poem. They are not what we would call non-representational. Yet, what do they represent? We discover a referential loop which ties together the visual and the verbal, and in the same gesture deconstructs them both (speech and writing). The drawing represents the letter, but also, this letter does not so much represent its verbal counterpart (these 
letters are not a script for the voice), as it does the fact that it is a drawing of a letter. The drawing surges up in the letter to expose the visuality of the letter, its drawability. In other words, the letter also represents the drawing. The visual dimension deconstructs the linguistic one and vice-versa. Likewise, the dual nature of both the sign and the image is called into question.

Image 2

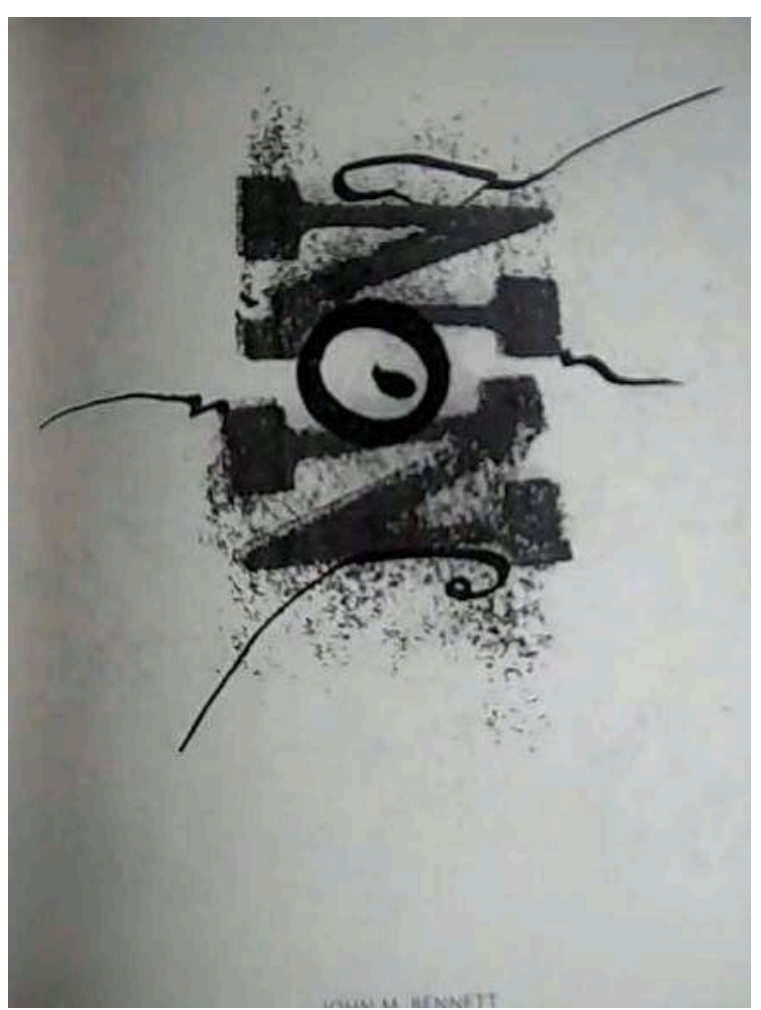

Even here, in this letter/phoneme poem which reads NON - a morpheme of sorts - it's not the word which reaches out to us, but a sort of amalgam of word and image, of the image of the word, of a word that means the image of the word. The letter represents the drawing that represents the letter which represented it. The visual sign calls out for the linguistic sign which in the same gesture calls out for the visual sign and so on. This is not a chronological relationship although the linear nature of the syntagm I am obliged to employ to describe it forces me to reproduce it as such.

This is one of the ways the visual poem may interrogate the traditional paradigms which infuse poetry and visual art with a divisional system of representation, as well as separate each domain from the other. Let us turn now to the work of another Xerolage poet, Geof Huth, who plays with this same dynamic of visual and linguistic signs but a little differently.

\section{Xerolage \#17: Geof Huth}

Despite the admirable efforts of Bohn's book to paint a comprehensive picture of visual poetry during his time period, Bohn is undoubtedly aware of the perhaps necessary violence done to the great diversity of visual poetry when attempting to elicit a cohesive theory of it. The tension (and the undoing of the traditional relationships 
founding them) between visual representation and linguistic representation that I elicited in Bennet's work is perhaps something common to all visual poetry. However, the relationship between these two dimensions is nowhere more complex and diverse than in visual poetry. Xerolage 17, The dreams of the fishwife $e^{6}$ by Geof Huth who illustrates this very clearly. Two strands of visual motif intertwine in this Xerolage, in a kind of double helix of syntagms.

In Huth's Xerolage \#17, we see two different intertwining sets of this similar impulse to explode the relationship between the visual and the phonetic (and also, to further complicate matters, the rhetorical) sign - which are here simultaneously simultaneous and disjunct.

Image 3

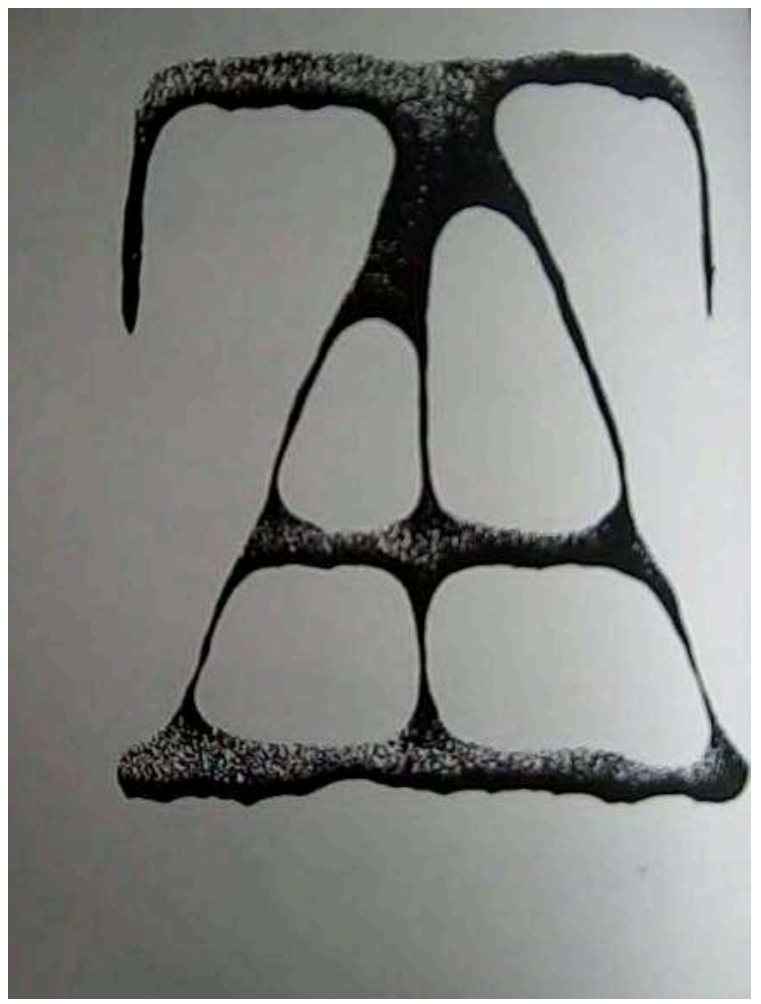

At first we approach the visual sign. This grapheme seems to pledge allegiance to the pictogram/hieroglyph/ideogram. However, it is a pictogram that although not a letter looks like a letter: a simulacrum or verisimilitude of a letter. It is a letter with no phoneme and no alphabet: in other words, it is completely flat, two dimensional, horizontal: nothing is absent. It is a kind of écriture blanche of the letter. What is absent is the letter: it represents the absence of itself.

The second strand that runs through this Xerolage lies on the other side of the grapheme/pictogram spectrum-it looks more "phonetic": 
Image 4

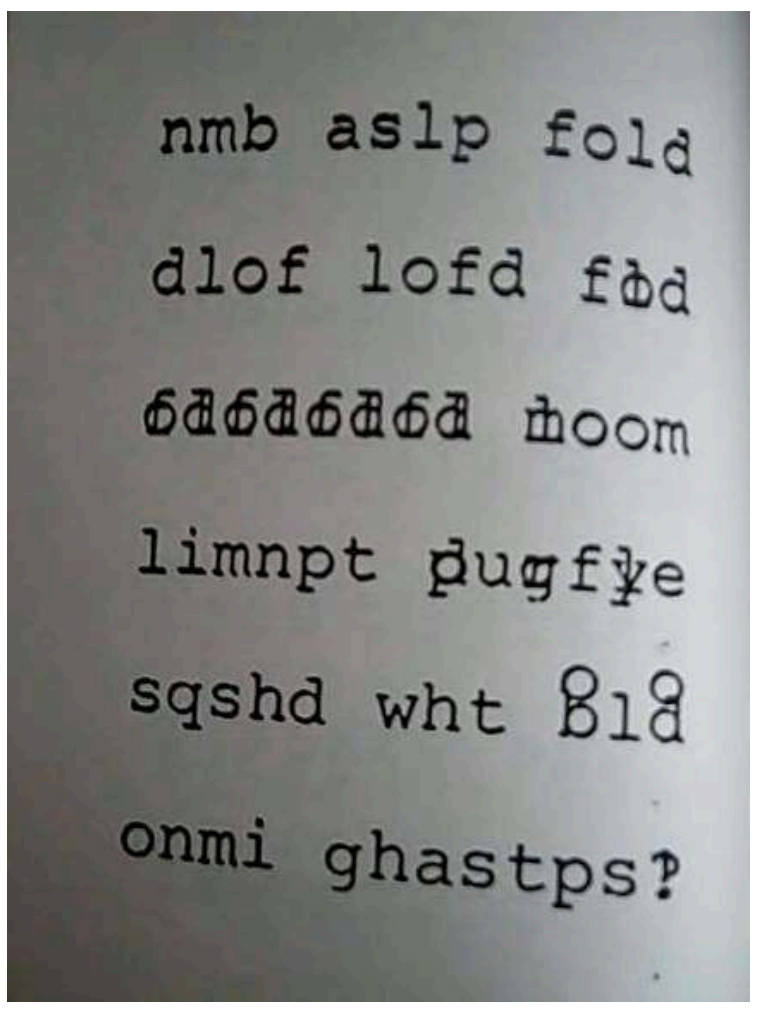

In other words, it looks like a text (that we can read) and likewise obeys several of the most essential reading conventions: letters arranged together in about the size of words, spaces in-between, left to right, top to bottom, arranged horizontally in rows. There is even punctuation. If one had no experience with the English language except for a cursory knowledge of the Roman alphabet (i.e. a visual acquaintance with the English language but not a semantic one), one would have no way of knowing that this text is not in fact, in the strict sense of the term, totally readable. Through the disruption of the linguistic space-and the space of reading - the linguistic sign reveals itself (again) to be visual (and not merely a signifier for an absent phoneme).

Aside from the obvious resonances between my reading of Huth's poems and Derrida's deconstruction of the metaphysics of speech and writing, this type of play also falls into what Craig Dworkin in his book, Reading the Illegible, refers to as "paragrammatics" (taken from Louis Roudiez's definition)-the rewriting, recycling, or misappropriating of systems of representation (or units within systems of representation), which serve to undermine the dominant paradigms which are at play within these systems. "A 'paragrammatic' reading is any reading that challenges the normative referential grammar of a text by forming 'networks of signification not accessible through conventional reading habits." (Dworkin, 2003: 11). Paragrammatics is tangentially political and historical in Dworkin's deployment, "paragrammatics-as a tactic for both reading and writing-manifests a certain politics within the realm of literature itself." (Dworkin, ibid).

There are innumerable ways to deconstruct the tension between the visual sign and the phonetic one, and also, perhaps in a similar, related gesture, to misappropriate the modes and codes of reading. For example, Huth's work rewrites or revises traditional approaches to writing and the image, and it uses paragrammatics to do so: the 
deployment of its form is an estrangement from the form it invokes: it rewrites, revises normative modes of representation.

What Huth's work also demonstrates is that visual poetry not only troubles the duality of the sign, but also the order of the alphabet. In Foucault's definition, and elsewhere, the law which instills division within the linguistic sign is also the law that orders and regulates difference within language. This is because language, and the law which orders it, is presumed to have a structural origin, which likewise infuses language with hierarchy.

At this early stage of our stroll through the Xerolage garden library, what is emerging as a trend-but not a rule-is that visual poetry troubles both a supposed (or imposed) duality of the sign as well as the order of and in language, and that these two notions follow one another. To disturb the normative hierarchy of phoneme and grapheme is likewise to upset alphabetical, textual and discursive order. To upset this order is likewise to disturb hierarchy within language. Using this language might perhaps bring out some possible social and political dimensions within visual poetry, and thus ally it with the social and political gesture of intentional community. In order to demonstrate better what I mean by this, let us to the work of Andrew Topel, Xerolage \#37.

\section{Xerolage \#37: Andrew Topel}

Image 5

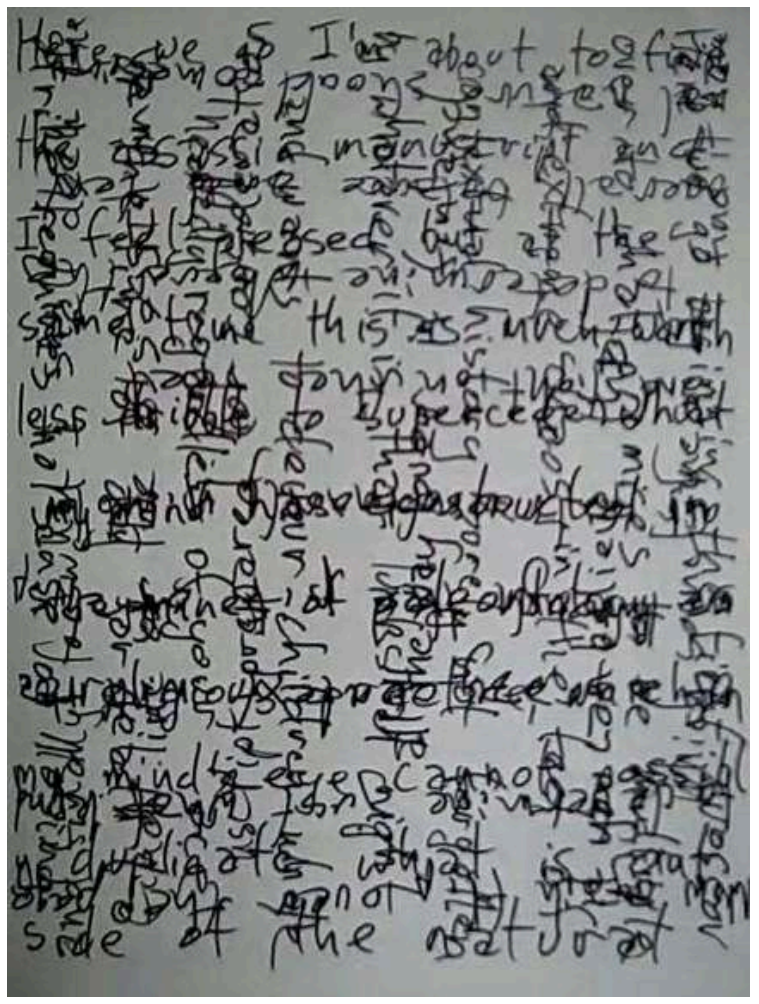

In Andrew Topel's poems, conventional reading practices are disturbed, and a new regime of reading order and hierarchy are employed. Here, for example we read from left to write, top to bottom, and then in order to continue reading we must reorient the page, turn the page horizontally, and then again to read "upside down." In fact we must 
read from a polyphony of directions. Topel's text "unsettles hierarchies by initiating a dialogue in a formerly monologic setting and inscribing multiple authors and multiple sites for the generation of meaning." (Dworkin, 2003: 13). The text is given to us as though we are sewing or crosshatching, rather than reading, with each strand of the text laid over one another, interfering with each other, interfering with the normal reading order. With a bit of patience one may decipher some of the text, as it weaves in and out of legibility.

Within the notion of paragrammatics that I mentioned previously, it is perhaps implied that a challenge to the dominant regime of the signifier is somehow analogous to a challenge to the dominant regime of political hegemony or social hierarchy. Issues of form, reading and systems of signification are necessarily inscribed into their historicity. In his explication of paragrammatics, Dworkin often sites the détournements of the Situationists. In Dworkin's book, certain instances of illegibility become moments of political resistance. I am also thinking of Deleuze and Guattari's criticism of Chomsky's regime of the "S": "la grammaticalité de Chomsky, le symbole catégoriel S qui domine toutes les phrases, est d'abord un marqueur de pouvoir avant d'être un marqueur syntaxique." (Deleuze and Guattari, 1980: 14). In this case, the disruption of the reading regime is at once an adoption and a refusal-a recycling and a deconstruction - of the hierarchies, habits and codes which ground language and reading. We read as we live: according to ideologically coded conventions. The disruption of an old system is the porthole to the invention of a new system.

Theoretically then, a thread emerges in which visual poetry may be ideologically aligned with political opposition. However, the goal of this paper is not to show that the practice and phenomenon of visual poetry may theoretically pose a threat to dominant symbolic regimes. Xerolage is not just an idea of visual poetry, it is a curatorial practice of reproduction and dissemination of visual poetry (it's a press). It likewise is part of a whole that includes Dreamtime Village, that it is to say an alternative community that not only socially and politically opposes itself to dominant culture, but also engages in subversive forms of growing food, making energy, structures: in short, of literally building civilization. Attempts to link conceptual apparati to practical engagement often proven impossible if not futile and I am not attempting to resolve the ever infuriating paradox of relating theory to practice. However, in this unique instance of Xerolage/Dreamtime village, I feel that Aira's notion quoted in the epigraph, of the construction of space as a kind of literature (literature as "unbuilt architecture") is particularly apt. That in a very real sense, Xerolage's poetry on the one hand and Dreamtime's community building and farming on the other, are spooled through the practices of its press. The press unites symbolic and practical imports.

I quote from Dreamtime's website: “Why 'Dreamtime' Village?”:

The name of Dreamtime was chosen from the aborigine philosophy/life style. Central to their belief system is that their dreams are real \& their waking life is a dream. (The Aztecs \& probably other cultures also operated on this belief.) Their 45,000 year old culture is the oldest uninterrupted sustainable culture on this planet. As hunters \& gatherers they have devoted a lot of time to ritual, tribal chanting, dancing, body painting, \& mask works, as means of maintaining a spiritual/psychic connection to plant \& animal life, far more intense than that of the western world. While our version of Dreamtime will pale next to theirs, it is an image of civilization which has powerful impact in the post-industrial Solar Age ${ }^{8}$. 
A quasi-anthropological trope of "original culture" comes to the surface. Of something like a more authentic organization of culture. A fantasy that in these "original" cultures the relationship between nature and language is not polluted, that the analogy between cultural images, phantasms and dramatizations and the organization of the social hierarchy is purer. In service of this fantasy, the traditional binary between dreams and reality has been inverted. Here, the dream is real and reality is the dream. But that is not all. At stake here is the even more practiced gesture of rewriting one's own culture through the lens of the other and by so doing, changing the reading order. In this case, the marginalized has been assimilated with the original or the central. I will explain how this is a kind of paragrammatics, and how it relates to the upheaval of the dynamics of the visual and verbal duality of the linguistic sign and interrupts reading conventions in the next part on Scott Helmes' Xerolage \#3.

\section{Xerolage \#3: Scott Helmes}

Image 6

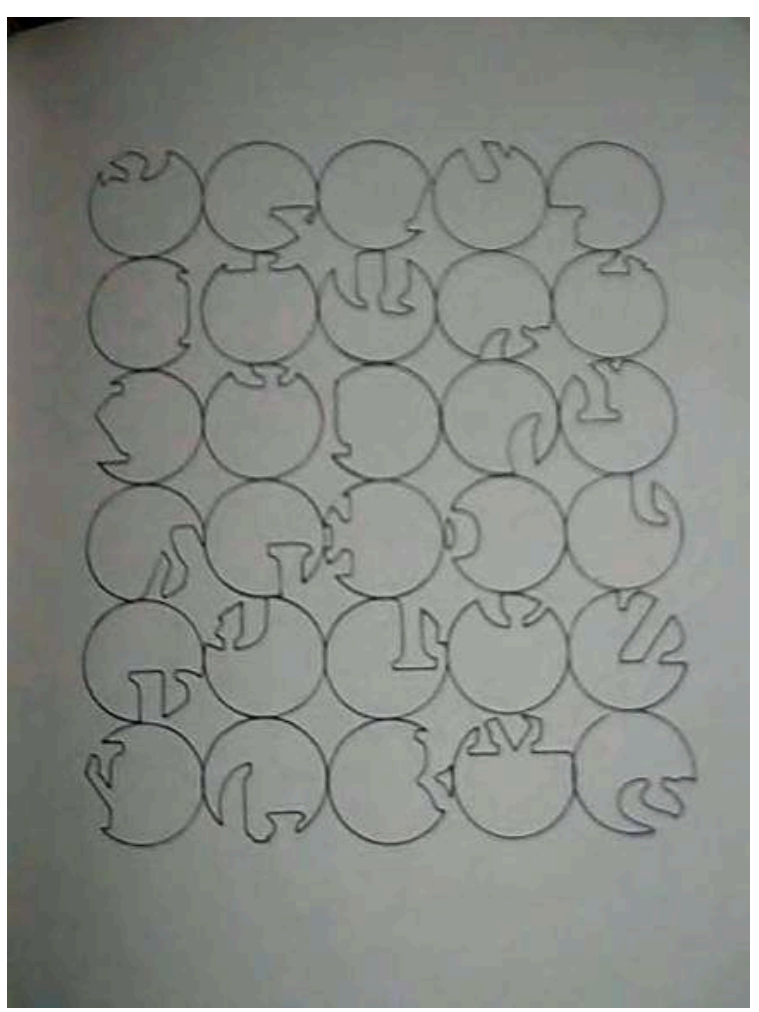

This poem functions as a series of negative re-enactments of the letter as holes punched from a text. In this way, language is made strange to us. Illegible. Yet, in this movement, we see other facets of language. Indeed this strange poem that is not a poem is arranged like a text on a page: it is composed of measured units, roughly the same size, but differentiable, in a block, slightly taller than it is wide. It has become different and thus enables us to see more clearly the same: it has détourned the binary of dream and reality, and also of signifier and signified. Here, the signifier does not signify the signified, rather, it has become liberated from the signified: the signifier is signifier of its own organization, of its own movement as text. It allows us to see 
structure as signified. And perhaps in this way, through a vision and a reading of structure, to disrupt our position within it.

What is most crucial to the Dreamtime blurb cited above, is that the interest Dreamtime has in aborigine culture is most closely related to the fact that that culture is "sustainable." The discourse on sustainability relies on a dual, juxtapositional but not necessarily contradictory rhetoric, that is embodied in the double meaning of the word "radical" as both root and opposition: that culture must both achieve something totally new and simultaneously return to its origins. That could be one definition of paragrammatics.

In Scott Helmes' we notice a manifest concern (although the work in this Xerolage is quite diverse) with revising reading conventions (again) and the desire to render language strange and new to itself: something like "shadows" of letters/text. This adoption of the strategies that are seen as innate to the structure of language is turned on its head in order to create something totally new. The impulse within visual poetry to trouble or disturb conventional reading practices and hierarchy within the sign is tied to a project that finds its roots in the movements that produced the earlier forms of visual poetry such as Dada and Futurism: the project of finding a new idiom. These poetries see traditional language as being tied to a corrupt social and political system. The possibility of discovering new modes of expression within language and elsewhere (of rendering language strange to itself), is thus concomitant-at least historically-to a political project to undo or reject dominant paradigms of hierarchy and order.

If visual poetry is part of this tradition of paragrammatics and social and political opposition, then Xexoxial editions is as well. However, how does Dreamtime accomplish or attempt to accomplish this oppositional gesture, apart from being the place where Xexoxial is edited?

Dreamtime originally began as Xexoxial Endarchy, Ltd. an experimental arts organization based in Madison, WI. (started in 1981). In 1991, five properties in the miniscule town of West Lima, WI., were donated to the organization. Already at its inset in Madison, Xexoxial Endarchy was active in both experimental arts as well as, "gourd growing, experimental gardening... earthworks, recycling of used and found materials, the combining of sculptural aesthetics with alternative energy production (for example, wind-machine sculpture), experimental small scale sustainable agriculture, \& in general, creative solutions to environmental problems.".

The two axes of experimental art and experimental living are inextricably woven together for the Xexoxial Endarchy/Dreamtime project. The project of experimental art and poetry are linked to the re-examining, revision and re-organization of culture. But also, the practical project of creating alternative energy and alternative food sources are indistinguishable from the desire to foment experimental creative activity among artists and social and environmental activists.

36 A good example of this type of activity is the aforementioned wind-machine sculpture, in which the production of alternative energy and artistic activity are combined into a single object. A homology of this activity in the Xerolage series is the use of found materials in David-Baptiste Chirot's FOUND rubBEings. 


\section{Xerolage \#32: David-Baptiste Chirot}

Image 7

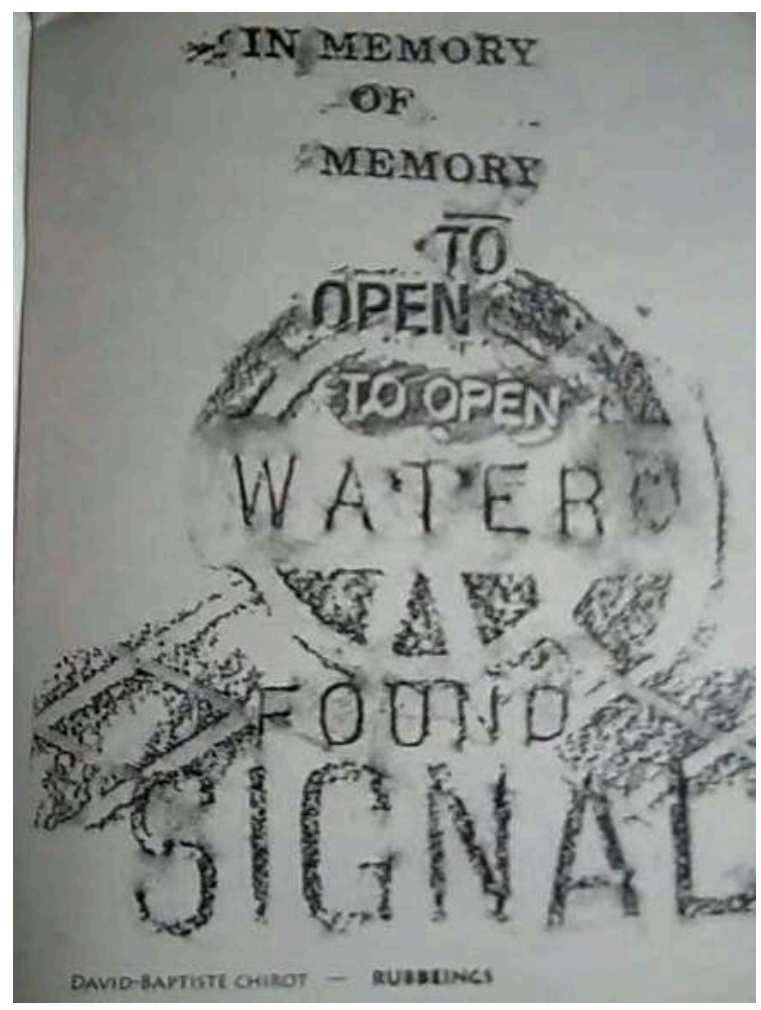

In Xerolage \#32, we can see how Chirot has collected found language, and created a détournement-a collage and recycling of signs in his environment. This is symptomatic of what I have been describing as paragrammatic: in other words, in this particular instance, what is radical in sustainability is also what is radical in visual poetry. As singular as this instance may be, this alliance is nevertheless indicative of the notion of paragrammatics, or détournement, in which the deeply conventional and historical structures and modes of representation are reappropriated in a movement which simultaneously shuts down and restarts (what perhaps is suggested also by the word deconstruction-which in French outside of the intellectual context is also used when remodeling or rehabbing a building).

Metonymically then, these practices of recycling and rebuilding can be seen both in much of the visual poetry Xerolage publishes as well as the concrete practices of habitat building and food growing at Dreamtime. Another dimension to this could be a process of on-going critique that I will again mime in the writing of this article, insofar as up to this point I have only cited men. Indeed, like a garden trying to grow and heal, Xerolage's catalogue seems to exponentially grow in its number of women writers. At the time of writing this article, only five of the 49 Xerolages were written by women, whereas of the 16 published since then, six are women. In this last section I will talk about one of the founders of Xerolage, herself a woman. 


\section{Xerolage \#9: Liz Was}

Liz Was (who died in 2004) uses a rhizomatic assemblage of typeset, drawings, parts of words, neologisms and collage. Liz Was's Xerolage was published in 1987, four years prior to founding of Dreamtime. The buildings donated to Xexoxial Editions in 1991 that would thus constitute Dreamtime village, exist in a mode of hybridity, collage and reappropriation similar to those used in her chapbook, such as the way the names of Dreamtime sites link them humorously to their historicity. For example, the "Hotel where visitors often stay" most certainly does not have any bellhops, concierges, credit checks nor any other commercial trappings of an actual hotel. Likewise, the "post office" - in a sort of intentional or unintentional homage to Apollinaire's Lettre Océan forms the sort of headquarters of Xexoxial Editions. It is also where mIEKAL aND, the other founder of Dreamtime, lives and makes his art. The names of other buildings, for example: "the schoolhouse," "the gym," and "the mansion" likewise invoke institutional apparati Dreamtime and Xexoxial fundamentally reject. This gesture of reappropriation and détournement within the realm of social organization, is both deeply paragrammatic and mimics the tactics employed in Liz Was's poems.

\section{Image 8}

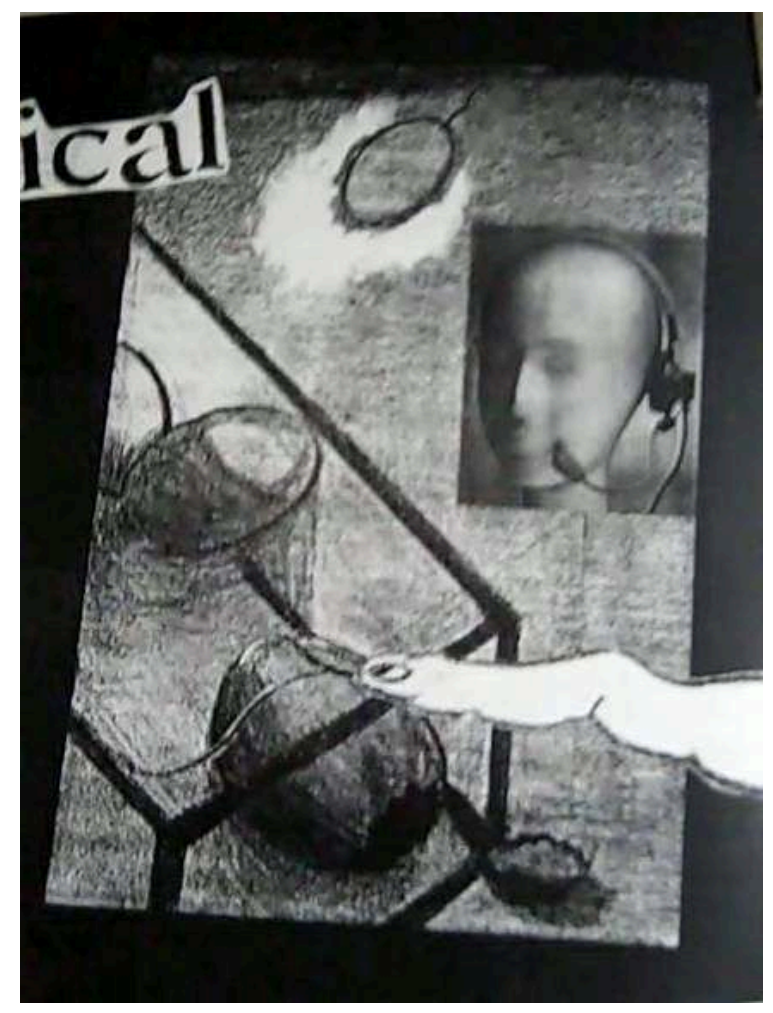

40 This practice of re-naming extends even to the participants of Dreamtime, mIEKAL aND and Liz Was in particular, whose influence on U.S. visual poetry and experimental art and literature of the past 20 years, through their role in Dreamtime Village, Xexoxial Endarchy and Xerolage as well as the impact of their own "writing," cannot be over emphasized.

41 Liz Was is also often cited in the Dreamtime community for her work with gourds in which, in addition to being edible may be used as "containers / utensils, musical and 
gaming devices [t'ou-hu], insect and bird cages, fishing floats, an artistic medium, etc." In a sense, her gourds, like her poetry use techniques of reappropriation and détournement although in a gesture that is far from ironic and also far from nouveau, since in reappropriating these gourds she is engaging in a traditional practice of exploiting the many uses of one object - a practice that puts the creator "back" into a symbiotic relationship with his/her natural environment. In the intersection between Liz Was' work with gourds and her work with collage lies the axis of the Xexoxial/ Dreamtime conjunction between practices of sustainable living and visual poetry. Likewise, we also uncover the strangely simultaneously divergent and parallel gesture that connects the rhetoric "return to the roots" to the impulse to begin again, start anew and call into question.

\section{Conclusion}

42 I would like to conclude by drawing a parallel between the twin ecologies of photocopy machine small press publishing and the practice of permaculture farming, two tools that are essential to the project of Xerolage and Dreamtime respectively. The photocopy machine belongs alongside the other great revolutions in the reproduction and distribution of text (the printing press, linotype, the airplane, the internet...). And like these other technologies, it played and plays a huge role in popularizing the distribution of literature and culture, as well as in the tangential operation of organizing social movement. In contrast to the book, the photocopy's principal function is to be fast and useful, rather than to produce monuments of history or beauty. It renders invisible or non-existent the division between subject and medium: that which is photocopied is significant precisely because it is innately multiple and therefore perceived of as temporary and disposable. The "copy" is the "original" (since the concept of "photocopy" is inconceivable without the copy). Consider for example, graffiti and street artists like Banksy and Obey who use photocopy machines to produce art the purpose of which is to be destroyed-to be recycled, written and pasted over, to epitomize the ephemeral, in other words, to become indistinguishable from the culture that produced it and will inevitably consign it to oblivion. It is in this way that the photocopy machine has become synonymous with radical social movements, with revolution, DIY and alternative culture. The photocopy machine makes art that exists within the same mode as the rest of the phenomena of capitalism, art that exists in the mode of that which has been produced and thus rejected by the consumerist machine. In other words, it is a détournement of the modes of capitalist production and reproduction. However, the photocopy machine is also deeply populist insofar as it is cheap and easy to access (Kinko's open all night). It functionally makes counter culture possible.

In what way can our relationship to the production and distribution of foodstuffs be allegorized by the example of the photocopy machine? The current U.S. agricultural/ gastronomical complex produces food in a similar way to the one in which the photocopy machine produces documents. Its only function is to produce and reproduce, mindlessly, without regard for source or waste. Photocopying is also easy and quick, like fastfood. What is photocopied often ends up in the recycling bin. Both the source and the conclusion are mere addenda to the photocopy machine into which you feed paper and out of which is produced paper. Likewise, in the U.S., relationships 
to the food that is produced and eaten is completely alienated, totally removed from the source of this food, its production and likewise the utter, staggering amount of waste that is produced by this system (a system that grows food not to feed people but to move capital-a machine into which you feed money and out of which is produced money).

Permaculture describes an approach to farming and community that attempts to mimic ecological relationships found in nature. For example by planting in layers and loops so that each layer/cycle of the garden may fertilize the other, utilizing all available space, planting crops that nourish and protect each other over the course of their life cycles.

The principle which inspires and encourages movements of permaculture farming across the world is both a means to grow food and a performance of criticism waged against capitalist modes of food production, waste and the gross global inequalities that produce it and result from it. Although originating from bifurcating threads, both the photocopy machine (as it is used in this context) and permaculture farming exist in tandem against the same great evil. Here lies an interesting alliance, since permaculture farming also employs many of the same techniques that artists who use the photocopy machine do. In spite of the photocopy machine's proclivity to produce unnecessary waste, permaculture farming and the photocopy machine both aim to popularize on the one hand, food and on the other, the reproduction of texts. Permaculture farming says, "grow your own food" while the photocopy machine says, "grow your own publications." And curiously enough, the methods and aesthetics expressed through art work historically produced on the photocopy machine are oddly synonymous with the logic of permaculture farming. I quote mIEKAL aND on permaculture farming: "The permaculture model [is] of multiple functions for a single element, loading a system for maximum edges \& diversity, \& the stacking of elements in closed system self-organizing loops ${ }^{10}$." (mIEKAL aND, 1999). I have perhaps never heard of a better description of the aesthetics and ecology of DIY "zines."

The tactics of distribution belonging to Xerolage likewise spring from their form of reproduction. A small press which grows a community as permaculture seeks to grow food: slowly ${ }^{11}$. They both also rely on natural, organically evolving networks that make use of every interstice of the available resources. These networks loop, recycle, print on demand, and function in opposition to the modes of production at work in the massive machines of consumer distribution.

The result of this conjunction between small press publishing and permaculture farming thus gives us something we might call "sustainable poetry". What I mean by that is that the logic of the détournement or of the paragrammatic shares some of its core rhetorical and aesthetic habits with those of the sustainability movement: namely the culturally critical activity inherent in recycling, and the reliance on experimentation to bring us there. It is perhaps that they both respond to a critical lacuna of the capitalist-consumer machine, or because they both emerge out of a similar social/cultural niche (something like "alternative" culture)-or perhaps something even deeper. Something that says that the way we live, the kind of shelters we build, the food we eat, water we drink, energy we use, is not a discourse divorced from the one that produces and disseminates symbols, rites, performance, music, art and literature. And that to genuinely pose a threat to the dominant paradigm we must challenge normative modes of reading, writing and gardening. Whatever its origins may be, there exists an underground visual and avant garde poetry publishing 
movement. There also exists a sustainability movement. Between these there also exists a third movement-that which sees sustainability, experimental writing, and independent publishing as being part of the same movement. This alliance only helps the other to grow stronger, and creates movements that say not that you are what you eat, but rather, you should read how you eat, and eat how you read.

\section{BIBLIOGRAPHIE}

\section{Xerolages}

Bennet, John M., Xerolage \#40, Duh Hud, Wisconsin: Xexoxial Editions, 2008.

Chirot, David-Baptiste, Xerolage \#32, "Rubbeings”, Wisconsin: Xexoxial Editions, 2006.

Helmes, Scott. Xerolage \#3, Wisconsin : Xexoxial Editions, 1985.

Huth, Geof. Xerolage \#17, dreams of the fishwife, Wisconsin: Xexoxial Editions, 1989.

Topel, Andrew. Xerolage \#37, Assassin, Wisconsin: Xexoxial Editions, 2005.

Was, Elizabeth, Xerolage \#9, Ound, Wisconsin: Xexoxial Editions, 1987.

\section{Other references}

Aira, César, Las Fantasmas, Buenos Aires, Grupo Editor Latinomarericano Collección Estritura de Hoy, 1990. Translation by Chris Andrews: Ghosts, New Directions, 1990.

aND, mIEKAL, "Hyper Wilderness/Hyper Culture", in N.J. Girardot (ed.), Myth and Meaning in Early Taoism; The theme of chaos, University of California Press, 1999.

Bohn, Willard, The Aesthetics of Visual Poetry, 1914-1928, Chicago, University of Chicago Press, 1993.

Deleuze, Gilles and Felix Guattari, Mille plateaux: capitalisme et schizophrenie, Paris, Les Editions de Minuit, 1980. Translation by Brian Massumi Brian: A Thousand Plateaus: Capitalism and Schizophrenia, University of Minnesota Press, 1987.

Drucker, Johanna, “Visual Poetics: An International View", in boundary 2, vol. 26, no. 1, 99 "Poets/ 1999: An International Poetics Symposium" (Spring, 1999), p. 100-104.

Dworkin, Craig, Reading the Illegible, Evanston, Northwestern University Press, 2003.

Foucault, Michel, Ceci n'est pas une pipe, Paris, Fata Morgana, 1973. Translation by Richard Howard in October, vol. 1, spring 1976.

Huth, Geof, "Visual Poetry Today", Poetry magazine, November 2008. https:// www.poetryfoundation.org/poetrymagazine/articles/69141/visual-poetry-today, page consulted July 72017.

Métail, Michèle, Le Vol des Oies Sauvages; Poèmes chinois à lecture retournée, IIIe siècle-XIX siècle, Saint-Benoît-du-Sault, Tarabuste, 2011. 


\section{NOTES}

1. This definition coincides thus roughly with the one given on the Fellowship for International Community website: http://www.ic.org, page consulted July 72017.

2. The definition of permaculture from the permaculture.org website reads: "Permaculture is an ecological design system for sustainability in all aspects of human endeavor. It teaches us how build natural homes, grow our own food, restore diminished landscapes and ecosystems, catch rainwater, build communities and much more."

3. At the time of publication this number has gone up to 65 .

4. Definition taken from the Trésor de la langue française: http://atilf.atilf.fr/

5. See Métail, Michèle, Le Vol des Oies Sauvages; Poèmes chinois à lecture retournée, IIIe siècle-XIX siècle.

6. See Free e-Library : "Read online The Dreams of the Fishwife (Xerolage 17) by Geof Huth ePub", https://galarchive.top/bookcase/read-online-the-dreams-of-the-fishwife-xerolage-17-by-geofhuth-epub.html, page consulted July, 122017.

7. "Chomsky's grammaticality, the categorical S symbol that dominates every sentence, is more fundamentally a marker of power than a syntactic power.” (trans : Brian Massumi, 1987: 7).

8. http://www.dreamtimevillage.org/, page consulted July 72017.

9. http://www.dreamtimevillage.org/faq.html, page consulted July 72017.

10. http://www.ibiblio.org/intergarden/permaculture/permaculture-list-archives-1999-2002oldversion/msg04708.html, page consulted July 72017.

11. The Green Lantern Press, a small, independent publisher in Chicago, as a form of guerilla marketing, distributes stickers reading: "we make slow culture like you like your slow food" (designed and produced by Caroline Picard, founder of the press).

\section{RÉSUMÉS}

Cet article traite de six auteurs de la collection Xerolage de la maison d'édition Xexoxial, qui publie de la poésie expérimentale. Xerolage imprime les «chapbooks », des petits livres de vingtcinq pages, en utilisant un photocopieur. Ces chapbooks sont imprimés à Dreamtime Village, une communauté intentionnelle à Lima, une ville du Wisconsin (Etats-Unis) fondée en 1991 par mIEKAL aND et Elisabeth Was où l'on pratique en particulier la "permaculture». L'article s'interroge sur les liens entre les pratiques d'écriture expérimentale, l'édition indépendante et les formes d'organisation sociales qui résistent aux paradigmes dominants. Le lien entre écriture expérimentale et résistance socio-politique est bien établi, notamment en ce qui concerne les avant-gardes. Ici cependant on reliera la poésie visuelle non seulement aux formes de résistance politique mais aux modes concrets de gestion du quotidien : logement, alimentation, etc. Nous voyons que dans les deux cas, ce travail créatif pose un défi aux principes d'ordre à la fois de la lecture et de la civilisation, en s'appuyant sur les stratégies paragrammatiques du détournement. Cette subversion passe par le recyclage, le collage, et la reconfiguration de passés perdus créant ainsi de nouvelles formes de résistances. Cet article présente le travail de John M Bennet, DavidBaptiste Chirot, Scott Helmes, Geof Huth, Andrew Topel, Elizabeth Was et mIEKAL aND.

This paper examines a cross section of authors in the Xerolage collection, a subsection of the experimental poetry publisher Xexoxial Editions. Xerolage prints 25-page chapbooks of visual 
poetry using a Xerox machine. These chapbooks are printed in an intentional community in Lima, Wisconsin founded in 1991 by mIEKAL aND and Elisabeth Was called Dreamtime Village, that practices alternative living and permaculture farming. The paper asks what kind of link can be made between these practices of experimental writing, small press DIY printing, and alternative, resistant forms of social organization. The link between experimental writing and social/political resistance is a well-established one, particularly with regards to the avant-garde tradition. In this instance, however, readings of visual poets will be interwoven not just with political resistance but with logistical ones related to the practical matters of community building: housing, eating, living. We see that in both instances, the work challenges principles of order, as they pertain to both reading and civilization, and uses paragrammatic strategies of détournement, subverting this order by recycling, cutting, pasting and rearticulating how resistance can be drawn newly from forgotten pasts. The article examines the work of John M Bennet, David-Baptiste Chirot, Scott Helmes, Geof Huth, Andrew Topel, Elizabeth Was and mIEKAL aND.

Este artículo se centra de manera pormenorizada en seis autores de la colección Xerolage, una parte de la editorial Xexoxial que publica poesía experimental. Xerolage imprime los «chapbooks », minilibros de unas 25 páginas cada uno, y para ello utiliza la fotocopiadora. Estos chapbooks están impresos en una comunidad intencional en Lima, Wisconsin, Estados Unidos, fundada en 1991 por mIEKAL aND y Elisabeth Was, llamada Dreamtime Village, donde se dan formas alternativas de vida tales como la « permacultura ». El artículo plantea el conocimiento de los tipos de lazos que se podrían establecer entre las prácticas de escritura experimental, la edición independiente y las formas de organización sociales que resisten a los paradigmas dominantes. El lazo entre la escritura experimental y la resistancia sociopolítica está claramente establecido, sobre todo en lo que concierne a las vanguardias. La particularidad de esta instancia estriba en la manera cómo se articula dicha poesía visual no solo con las formas de resistencia política, sino también con las de la logística en lo que concierne a lo cotidiano: la vivienda, el bricolaje, la comida, etc. Vemos que en ambos casos este trabajo plantea un desafío a los principios de ordenamiento a la vez de la lectura y de la civilización, apoyándose en estrategias paragramáticas del derivar. Dicho trabajo altera el orden mediante el reciclaje, el collage y el despliegue de los pasados perdidos en la creación de nuevas formas de resistencias. Este artículo pone de realce el trabajo de John M Bennet, David-Baptiste Chirot, Scott Helmes, Geof Huth, Andrew Topel, Elizabeth Was and mIEKAL aND.

INDEX

Mots-clés : poésie visuelle, écriture expérimentale, communauté intentionnelle, maison d'édition indépendante, agriculture permaculture, avant-garde, photocopie

Palabras claves : poesía visual, escritura experimental, comunidad intencional, editorial independiente, agricultura permacultura, vanguardia, fotocopia

Keywords : visual poetry, experimental writing, intentional community, small press publishing, permaculture farming, avant-garde, photocopy

\section{AUTEUR}

\section{LILY ROBERT-FOLEY}

Lily Robert-Foley est maîtresse de conférences à l'Université Paul-Valéry Montpellier 3, où elle est spécialiste de la traductologie. Elle est l'auteure notamment de Jiji, un livre de poésie en prose et écriture conceptuelle (Omnia Vanitas, 2016), Money, Math and Measure (Essay Press, 2016) m, un 
livre de poésie-critique-collage (Corrupt Press, 2013), graphemachine, a mini-livre de poésie visuelle (Xerolage, 2013), et la traduction de La Chambre sous le saule de Sophie Loizeau (The Room under the Willow Tree). lilyrobertfoley@gmail.com, lilyrobertfoley@univ-montp3.fr 